\title{
Prevalensi Hasil Pemeriksaan HBsAg dan Anti HBs pada PSK (Pekerja Seks Komersial)
}

\section{Prevalence of HBsAg and Anti HBs Examination Results in Prostitute

\author{
DJOKO PRIYATNO \\ NURUL QOMARIAH
}

\author{
Jurusan Analis Kesehatan Poltekkes Kemenkes Semarang \\ Jl. Wolter Monginsidi Pedurungan Tengah Semarang \\ Email:djokopriyatno@ymail.com
}

\begin{abstract}
Abstrak
Pekerja seks komersial merupakan kelompok risiko tinggi infeksi PMS (HIV-AIDS, Sifilis, Gonorhoe dan Hepatitis-B). Penularan VHB 100x lebih cepat dari virus HIV. Diagnosis HBsAg dan Anti HBs merupakan petanda infeksi VHB yang dapat dideteksi minimal 2 minggu sebelum gejala klinik muncul. Angka kejadian IMS kota Semarang (tahun 2012) tertinggi pada Resosialisasi Argorejo kota Semarang sebanyak 1.623 kasus. Monitoring penyakit Hepatitis B pada PSK Resosialisasi belum menjadi pemeriksaan rutin. Rumusan permasalahan penelitian adalah "Bagaimana Prevalensi hasil pemeriksaan HBsAg dan Anti-HBs pada PSK Resosialisasi Argorejo Kota Semarang?". Penelitian ini merupakan penelitian Observasional Analitik dengan rancangan cross sectional. Spesimen penelitian adalah darah vena PSK Resosialisasi Argorejo Kota Semarang yang periksa monitoring HIV-AIDS pada bulan Agustus-September 2015. Pengambilan sampel secara total sampling untuk pemeriksaan HBsAg dan Anti-HBs secara imunoserologis metode strip. Analisis hubungan antara faktor pejamu dengan HBsAg dan Anti-HBs menggunakan uji statistik spearman's test. Nilai negatif pada hasil pemeriksaan HBsAg sedangkan prosentase Anti-HBs PSK Resosialisasi Argorejo Kota Semarang sejumlah 29\%. Tidak ada hubungan antara faktor usia, pendidikan dan pengetahuan dengan hasil pemeriksaan Anti-HBs. Ada hubungan antara perilaku seksual dengan hasil pemeriksaan Anti-HBs. Diperlukan peningkatan regulasi penapisan dan imunisasi infeksi Hepatitis-B pada komunitas Resosialisasi Argorejo Kota Semarang.
\end{abstract}

Kata Kunci: Hepatitis-B ; HBsAg, Anti-HBs ; PSK ; Pekerja Seks Komersial

\begin{abstract}
Commercial sex workers are a high risk group of STD infection (HIV-AIDS, syphilis, gonorrhea and Hepatitis-B). Transmission of HBV 100x faster than the HIV. Diagnosis $H B s A g$ and Anti-HBs is a marker of HBV infection can be detected at least 2 weeks before clinical symptoms appear. The incidence of STIs Semarang (in 2012) is the highest in the resocialization Argorejo as much as 1,623 cases. Monitoring of Hepatitis $B$ in resocialization has not become a routine examination. The formulation of the research problem is "How prevalence of HBsAg and Anti-HBs on resocialization PSK Argorejo Semarang?". This study is observational analytic cross-sectional design. Specimens research is venous blood PSK Argorejo resocialization who check monitoring of HIV-AIDS in August-September 2015. Sampling a total of sampling for examination imunoserologis HBsAg and Anti-HBs in the strip method. Analysis of the relationship between host factors with HBsAg and anti-HBS using Spearman's test. Negative values on the results of HBsAg while the percentage of anti-HBs PSK resocialization some 29\%. There is no relationship between age, education and knowledge with Anti-HBs. There is a relationship between sexual behavior with
\end{abstract}


Anti-HBs. Upregulation required screening and immunization of Hepatitis-B infection in the community resocialization Argorejo Semarang.

Keyword: Habits handwashing ; Infection of Soil Transmitted Helminths ; Prostitute

\section{Pendahuluan}

Hepatitis B merupakan masalah kesehatan global, diperkirakan sekitar 2 miliar penduduk dunia pernah terpapar virus hepatitis B (VHB). Prevalensi infeksi VHB di Asia Pasifik cukup tinggi yaitu melebihi $8 \%$ dan penularannya pada umumnya terjadi secara vertikal (pada periode perinatal) dan horizontal (pada masa anak-anak), oleh karena itu risiko menjadi kronis cukup besar. Sekitar 75\% pengidap hepatitis B kronis karier berada di Asia Pasifik. Sirosis hati, gagal hati, atau kanker hati dapat terjadi pada $15-40 \%$ penderita dengan infeksi hepatitis B kronis. Di negara berkembang orang dewasa sangat berisiko tinggi untuk terkena hepatitis B, terlebih di negara miskin. Tingginya morbiditas dan mortalitas karena hepatitis B, penyebabkan penyakit ini sangat mengancam di dunia (WHO, 2004; Lafanchy D, 2004).

Penyakit ini dapat menimbulkan hal yang serius dan mengakibatkan kerusakan hati dan dapat berakhir dengan kematian atau kanker hati. Hepatitis B terdiri dari antigen permukaan (surface antigen) yang disebut dengan antigen Australia, karena antigen ini pertama kali dijumpai di Australia (Sherlock, 2002).

Masa inkubasi penyakit Hepatitis B antara 45-180 hari dan lama masa inkubasi tergantung pada jumlah virus yang masuk ke dalam tubuh dan cara penularan serta daya tahan pasien. Penyakit ini sering dijumpai pada $30-50 \%$ pada usia $>50$ tahun dan $10 \%$ pada usia $<50$ tahun. Keluhan pada penyakit Hepatitis B: mual tidak nafsu makan, lemas, muntah, nyeri pada otot dan sendi, demam, kencing berwarna cokelat tua dan kulit berwarna kuning (Dienstaq, 2004).

Virus hepatitis B menular melalui kontak dengan cairan tubuh. Manusia merupakan satu-satunya host (pejamu) dari virus ini. Darah merupakan faktor penting untuk media penularan. Cairan tubuh yang lain juga faktor penting untuk penularan. Ada tiga cara penularan virus hepatitis B. Pertama adalah transmisi perinatal, seksual, parenteral dan perkutaneus (menggunakan jarum suntik yang sama secara bergantian). Melalui pemeriksaan penyaring pada darah transfusi, infeksi penyakit Hepatitis B berkurang sekitar 0,3-0,9 \% pada pasien yang mendapatkan transfusi. Angka kejadian infeksi VHB tinggi pada pasien yang mendapatkan tranfusi berulang atau komponen darah yang berasal dari donor multipel, pasien dengan hemodialisi, pecandu narkoba, luka tusuk dengan jarum suntik atau alat kesehatan lain yang telah terkontaminasi, akupuntur, tatto, pegawai medis, transmisi dari ibu ke bayi dan penggunaan pisau cukur bersama penderita Hepatitis B (Lok, 2004).

Tingkat penularan Virus Hepatitis B (VHB) 100 kali lebih cepat dibanding dengan virus HIV. Penularan infeksi VHB dapat melalui penularan horizontal dan penularan vertikal. Penularan horizontal terjadi dari seorang pengidap infeksi VHB kepada individu yang masih rentan di sekelilingnya salah satunya adalah para PSK mengingat dalam hal servis melayani pelanggan dengan berbagai macam cara dilakukan. Penularan horizontal dapat terjadi melalui kulit atau melalui selaput lendir sehingga untuk pencegahannya bagi para PSK dengan mematuhi penggunaan kondom pada setiap melayani pelanggan serta melakukan vaksinasi Hepatitis B. Sedangkan penularan vertikal terjadi dari seorang pengidap yang hamil kepada bayi yang dilahirkannya (Daili, 1999; 2009).

Menurut United Nations Developement Program (UNDP) pada 2003 krisis ekonomi di Indonesia yang sudah terasa sejak awal 1998 di Indonesia terdapat 190-270 ribu wanita Pekerja Seks Komersial (PSK) dengan 7-10 juta pelanggan (Basyuni, 2008).

Resosialisasi di kota Semarang ada dua yaitu Resosialisasi Argorejo (Sunan Kuning) dan Resosialisasi Gambilangu Mangkang. Angka kejadian Infeksi Menular Seksual (IMS) 
tahun 2012 tertinggi yaitu Resosialisasi Sunan Kuning Semarang sebanyak 1.623 kasus, sedangkan di Resosialisasi Gambilangu sebanyak 760 kasus (Semarang, 2012).

Tujuan penelitian ini adalah mengetahui interaksi antara faktor pejamu dengan hasil pemeriksaan HBsAg dan Anti HBs pada PSK Resosialisasi Argorejo kota Semarang.

\section{Metode}

Penelitian ini merupakan penelitian Observasional Analitik yang menjelaskan interaksi antara faktor pejamu dengan hasil pemeriksaan HBsAg dan Anti-HBs pada PSK Resosialisasi Argorejo Kota Semarang, dengan rancangan penelitian cross sectional. Sampel dalam penelitian ini adalah PSK Resosialisasi Argorejo Kota Semarang yang periksa rutin monitoring HIV/AIDS yang berkunjung di Laboratorium Klinik Griya ASA PKBI Semarang dari bulan Agustus sampai September 2015 secara total sampling. Instrumen penelitian; Kuesioner, Tabung vacutainer, Needle vacutainer, Rak tabung, mikropipet, yellow tip, kapas alcohol, torniquet masker, handscoon, tissue, kantong limbah klinis, hipafix, Lysol / bayclin, Strip HBsAg dan Anti HBs.

Langkah pemeriksaan HBsAg dan Anti HBs metode Strip ; pengambilan darah vena, pembuatan serum, pemeriksaan HBsAg dan anti HBs.

\section{Hasil dan Pembahasan}

\section{Hasil}

Sampel yang diperoleh selama penelitian sejumlah 100 orang dengan kisaran usia 19-50 tahun dan rata-rata berusia $30 \pm 7$ tahun. Namun demikian yang bersedia mengisi lembaran kuestioner dengan baik sejumlah 79 orang (79\%).

Sebagian besar berpendidikan sekolah dasar dan tidak mempunyai pasangan tetap (suami). Data lengkap karakteristik sampel tersaji pada tabel 1.

Tabel 1. Karakteristik Sampel Penelitian

\begin{tabular}{|c|c|c|}
\hline Karakterisasi & Jumlah & $\begin{array}{c}\text { Prosentase } \\
(\%)\end{array}$ \\
\hline \multicolumn{3}{|l|}{ Pasangan Tetap } \\
\hline Punya & 15 & 19,0 \\
\hline Tidak Punya & 64 & 81,0 \\
\hline \multicolumn{3}{|l|}{ Lama Bekerja } \\
\hline$>5$ tahun & 12 & 15,2 \\
\hline 1-5 tahun & 46 & 58,2 \\
\hline$<1$ tahun & 21 & 26,6 \\
\hline \multicolumn{3}{|l|}{ Pelanggan per pekan } \\
\hline$>5$ orang & 28 & 35,4 \\
\hline $3-5$ orang & 27 & 34,2 \\
\hline$<3$ orang & 24 & 30,4 \\
\hline \multicolumn{3}{|l|}{ Status Kehamilan } \\
\hline Hamil & 2 & 2,5 \\
\hline Tidak Hamil & 77 & 97,5 \\
\hline \multicolumn{3}{|l|}{ Pengetahuan tentang Hepatitis } \\
\hline Baik & 12 & 15,2 \\
\hline Kurang & 67 & 84,8 \\
\hline \multicolumn{3}{|l|}{ Sikap tentang Hepatitis } \\
\hline Cukup Baik & 26 & 32,9 \\
\hline Kurang Baik & 53 & 67,1 \\
\hline
\end{tabular}


Hasil pemeriksaan pada 100 sampel diperoleh nilai negatif $\mathrm{HBsAg}$ untuk seluruh spesimen darah sampel, sedangkan nilai anti HBs diperoleh 25 sampel (25\%) positif mengandung HBs.

Berdasarkan tabel 2., sebagian besar sampel (73,4\%) menjadi PSK sudah lebih dari satu tahun dan sekitar 55 orang $(69,6 \%)$ melayani pelanggan minimal 3 pelanggan per pekan.

Tabel 2. Tabulasi Silang Lama Bekerja Dengan Jumlah Pelanggan Per Satu Pekan

\begin{tabular}{|c|c|c|c|c|c|c|c|c|}
\hline \multirow{3}{*}{ Lama kerja } & \multicolumn{4}{|c|}{ Jumlah pelanggan per satu pekan } & \multicolumn{4}{|c|}{ Total } \\
\hline & \multicolumn{2}{|c|}{$<3$ orang } & \multicolumn{2}{|c|}{$3-5$ orang } & \multicolumn{2}{|c|}{$>5$ orang } & \multirow[b]{2}{*}{$\mathrm{n}$} & \multirow[b]{2}{*}{$\%$} \\
\hline & $\mathrm{n}$ & $\%$ & $\mathrm{n}$ & $\%$ & $\mathrm{n}$ & $\%$ & & \\
\hline$<1$ Thn & 7 & 33,3 & 3 & 14,3 & 11 & 52,4 & 21 & 100,0 \\
\hline 1-5 Thn & 16 & 34,8 & 19 & 41,3 & 11 & 23,9 & 46 & 100,0 \\
\hline$>5 \mathrm{Thn}$ & 1 & 8,3 & 5 & 41,7 & 6 & 50,0 & 12 & 100,0 \\
\hline Total & 24 & 30,4 & 27 & 34,2 & 28 & 35,4 & 79 & 100,0 \\
\hline
\end{tabular}

Pada tabel 3. diketahui bahwa hanya 12 sampel $(15,2 \%)$ mempunyai pengetahuan yang baik tentang penyakit Hepatitis B, dan 53 sampel $(67,1 \%)$ mempunyai sikap yang kurang baik.

Tabel 3. Tabulasi Silang Pengetahuan Hepatitis B Dengan Sikap Tentang Hepatitis B

\begin{tabular}{ccccccc}
\hline \multirow{3}{*}{ Pengetahuan } & \multicolumn{2}{c}{ Sikap } & \multicolumn{6}{c}{ Total } \\
\cline { 2 - 7 } & Kurang & \multicolumn{2}{c}{ Baik } & & \\
\cline { 2 - 7 } & $\mathrm{n}$ & $\%$ & $\mathrm{n}$ & $\%$ & $\mathrm{n}$ & $\%$ \\
\hline Kurang & 49 & 73,1 & 18 & 26,9 & 67 & 100,0 \\
Baik & 4 & 33,3 & 8 & 66,7 & 12 & 100,0 \\
\hline Total & 53 & 67,1 & 26 & 32,9 & 79 & 100,0 \\
\hline
\end{tabular}

Pada umumnya (92\%) sampel yang positif anti HBs mempunyai pengetahuan tentang penyakit Hepatitis B masih kurang.

Tabel 4. Tabulasi Silang Pengetahuan Hepatitis B Dengan Hasil Pemeriksaan Anti HBs

\begin{tabular}{ccccccc}
\hline \multirow{2}{*}{$\begin{array}{c}\text { Pengetahu } \\
\text { an }\end{array}$} & \multicolumn{2}{c}{ Pemeriksaan Anti HBs } & \multicolumn{2}{c}{ Total } \\
\cline { 2 - 6 } & $\mathrm{n}$ & $\%$ & $\mathrm{n}$ & $\%$ & $\mathrm{n}$ & $\%$ \\
\hline Kurang & 44 & 65,7 & 23 & 34,3 & 67 & 100,0 \\
Baik & 10 & 83,3 & 2 & 16,7 & 12 & 100,0 \\
\hline Total & 54 & 68,4 & 25 & 31,6 & 79 & 100,0 \\
\hline
\end{tabular}

Hasil penelitian yang tersaji pada tabel 5, memberi informasi bahwa 20 sampel terdeteksi positif (80\%) mempunyai sikap yang "Kurang Baik".

Tabel 5. Tabulasi Silang Sikap Tentang Hepatitis Dengan Hasil Pemeriksaan Anti HBs

\begin{tabular}{ccccccc}
\hline \multirow{2}{*}{ Sikap } & \multicolumn{3}{c}{ Pemeriksaan Anti HBs } & \multicolumn{2}{c}{ Total } \\
\cline { 2 - 5 } & \multicolumn{2}{c}{ Negatif } & \multicolumn{2}{c}{ Positif } & & \\
\cline { 2 - 6 } & $\mathrm{n}$ & $\%$ & $\mathrm{n}$ & $\%$ & $\mathrm{n}$ & $\%$ \\
\hline Kurang & 33 & 62,3 & 20 & 37,7 & 53 & 100,0 \\
Baik & 21 & 80,8 & 5 & 19,2 & 26 & 100,0 \\
\hline Total & 54 & 68,4 & 25 & 31,6 & 79 & 100,0 \\
\hline
\end{tabular}




\section{Pembahasan}

Tingkat pendidikan sampel sebagian besar berpendidikan sekolah dasar dan sekolah lanjut pertama, sehingga pengetahuan dan pemahaman tentang penyakit Hepatitis B masih sangat kurang. Hal ini ditunjang dengan belum optimalnya upaya preventif penularan penyakit Hepatitis B di lingkungan Resosialisasi Argorejo Kota Semarang.

Sebagian besar sampel sudah bekerja sebagai PSK lebih dari satu tahun dengan rata-rata per pekan melayani lebih dari 3 (tiga) pelanggan. Kondisi ini memungkinkan untuk penularan penyakit Hepatitis B menjadi lebih masif, hal didukung pula dengan penggunaan kondom yang sangat minim.

Pengetahuan sampel tentang pemanfaat kondom pada umumnya baik, namun demikian penggunaan kondom sangat minim. Hal ini dapat terjadi karena pelanggan menolak penggunaan kondom dengan alasan utama adalah ketidaknyamanan. Kondisi inilah yang membuat komunitas sampel termasuk yang berisiko tinggi untuk mengalami infeksi menular seksual.

Pada penelitian ini diketahui bahwa ada sampel yang hamil, sehingga yang bersangkutan dapat menjadi pembawa penularan infeksi menular seksual kepada janin yang dikandungnya. Hal ini dikarenakan penularan penyakit IMS tidak hanya melalui hubungan seksual, namun juga dapat menular melalui interaksi ibu dengan janin yang dikandungnya.

Hasil pemeriksaan serum darah sampel positif anti HBs menunjukkan bahwa pasien dianggap memiliki kekebalan terhadap Hepatitis B (baik karena infeksi yang telah sembuh atau karena vaksinasi). Namun demikian dari hasil daftar pertanyaan (kuestioner) yang berkaitan dengan vaksinasi atau imunisasi, pada umumnya sampel tidak paham atau tidak ingat tentang vaksinasi atau imunisasi yang pernah didapat.

Hasil uji Spearman's test menunjukkan bahwa tidak ada hubungan yang bermakna secara statistik antara pengetahuan dan sikap dengan hasil pemeriksaan HBsAg. Demikian pula pada hubungan antara pengetahuan dengan hasil pemeriksaan anti HBs diketahui bahwa tidak ada hubungan antara kedua variabel tersebut.Pada interaksi antara sikap dengan hasil pemeriksaan anti HBs, berdasarkan Spearman's test diperoleh nilai p value 0,042 $(>\alpha 0,05)$ dan koefisien korelasi $-0,230$. Nilai $\mathrm{p}$ value tersebut menunjukkan adanya hubungan yang bermakna secara statistik antara sikap dengan hasil pemeriksaan anti HBs.

Nilai koefisien korelasi menunjukkan bahwa keeratan hubungan kedua variabel sangat lemah dengan arah yang terbalik (negatif).

Adapun interaksi antara pengetahuan dengan sikap tentang Hepatitis diperoleh nilai $\mathrm{p}$ value $0,000(>\alpha 0,05)$ dan koefisien korelasi 0,384 . Nilai $\mathrm{p}$ value tersebut menunjukkan adanya hubungan yang bermakna secara statistik antara pengetahuan dengan sikap tentang Hepatitis. Nilai koefisien korelasi menunjukkan bahwa kedua variabel memiliki keeratan yang cukup kuat dengan arah positif.

\section{Simpulan dan Saran}

\section{Simpulan}

Identifikasi karakterisasi PSK Resosialisasi Argorejo kota Semarang ; tidak bersuami (81\%), sudah bekerja lebih dari 1 tahun $(73,4 \%)$, memiliki pelanggan tetap lebih dari 3 orang per pekan $(69,6 \%)$, sedang hamil $(2,5 \%)$, pengetahuan tentang Hepatitis masih kurang $(84,8 \%)$, sikap tentang Hepatitis masih kurang baik $(67,1 \%)$.

Semua sampel negatif HBsAg.

Prosentase hasil pemeriksaan Anti-HBs pada PSK Resosialisasi Argorejo Kota Semarang sejumlah $25 \%$.

Tidak ada hubungan antara pengetahuan dan sikap tentang hepatitis dengan hasil pemeriksaan HBsAg dan pada PSK Resosialisasi Argorejo Kota Semarang. 
Tidak ada hubungan antara pengetahuan tentang hepatitis dengan hasil pemeriksaan anti HBs pada PSK Resosialisasi Argorejo Kota Semarang.

Ada hubungan antara sikap tentang hepatitis dengan hasil pemeriksaan anti HBs pada PSK Resosialisasi Argorejo Kota Semarang.

Ada hubungan antara pengetahuan tentang hepatitis dengan sikap tentang hepatitis pada PSK Resosialisasi Argorejo Kota Semarang.

\section{Saran}

Penyuluhan dan peningkatan pengetahuan serta pemahaman komunitas Resosialisasi Argorejo Kota Semarang mengenai infeksi Hepatitis B.

Peningkatan regulasi penapisan dan imunisasi infeksi Hepatitis B di komunitas Resosialisasi Argorejo Kota Semarang.

Penelitian lebih lanjut di komunitas PSK Kota Semarang yang melibatkan Dinas Kesehatan Kota Semarang dan Yayasan Laboratorium Klinik Griya ASA PKBI Semarang.

\section{Daftar Pustaka}

Basyuni, Muhammad M. 2008. Peran Komunitas Lintas Agama dalam Pencegahan HIV/AIDS. Diunduh tanggal 9 Juli 2015 dari http://satudunia.oneworld.net/?q=node/1393.

Daili, Syaiful Fahmi. 1999. PMS. Jakarta : Balai Penerbit FKUI.

Daili, Syaiful Fahmi, dkk. 2009. Infeksi Menular Seksual edisi 4. Jakarta : Balai Penerbit FKUI. Dalam Widiyana, Trisna. 2014. Karya Tulis Ilmiah : Hubungan Sikap PSK dan Dukungan sesama PSK terhadap Sikap Penggunaan Kondom.

Dienstaq JL, Isselbacher KJ. 2004. Acute Viral Hepatitis.In:Braunwald E. etal., Harrison's Principles of Internal Medicine, 16th edition. New York : Mc Graw Hill.

Lafanchy D. 2004. Hepatitis B Virus epidemiology, disease burden, treatment, and current and emerging prevention and control measures. $J$ Viral Hepat ;11:97-107.

Lok ASF, McMahon BJ. 2004. Chronic Hepatitis B: Update of Recommendations in AASLD Practice Guideline. Hepatology, 39(3).

Semarang. Dinas Kesehatan Kota. 2012. Profil Kesehatan Kota Semarang 2012. Semarang : Dinas Kota Semarang.

Sherlock S, Dooley J. 2002. Hepatitis B virus and Hepatitis Delta virus. In Disease of the Liver and Biliary System (11th ed. pp 285 - 302). London : Blackwell Scienc

World Health Organization. 2004. Hepatitis B. World Health Organization Fact Sheet. Diunduh tanggal 6 Desember 2015 dari http://who.int/mediacentre/ factsheets/fs204/en 